\title{
SINGAPURA DAN ASEAN: ANALISIS RELASI NEGARA DAN INSTITUSI KAWASAN DI TENGAH PANDEMI COVID-19
}

\author{
Riska Putri Hariyadi
}

\begin{abstract}
Increased interstate connectivity has led to the mobility of the COVID-19 outbreak easily spread throughout the world, including Southeast Asia. This outbreak has a multi-dimension effect that encourages countries to take two possibilities, Collaboration to handle the outbreak or by issuing restrictions as protection measures. Through this paper, the author describes the relations that occur in the Southeast Asian region by analyzing Singapore and ASEAN in the face of the outbreak. This paper argues that Singapore and ASEAN show commitment to the handling of the COVID-19 outbreak through regional cooperation such as the Asean COVID-19 Response Fund and solidarity actions with member countries.
\end{abstract}

Keywords: COVID-19, Singapura, ASEAN, Regional Cooperation

\section{PENDAHULUAN}

Bermula dari Wuhan dan menyebar ke seluruh pelosok dunia, kini masyarakat dunia menghadapi permasalahan kesehatan yang berdampak secara multi-dimensi. Hal ini menunjukkan konektivitas antarnegara telah mendorong mobilitas virus yang luas dan berimplikasi kepada peningkatan jumlah kasus terkonfirmasi setiap harinya. Kawasan Asia Tenggara menjadi salah satu kawasan yang terdampak oleh wabah COVID-19. Berdasarkan laporan World Health Organization (WHO) tercatat ada 264.0153 kasus terkonfirmasi di kawasan Asia Tenggara (WHO, 2020). Negara-negara di kawasan yang tergabung dalam Association of South-East Asia Nation (ASEAN) tercatat mengalami

${ }^{3}$ Data yang ditampilkan mewakili jumlah kasus pada tanggal 1 Juni 2020. Jumlah kasus terkonfirmasi dapat berubah dan bertambah secara real time. Data ini dapat diakses dalam

https://covid19.who.int/ 
permasalahan yang sama. Melalui sumber yang sama, Singapura tercatat sebagai negara dengan kasus terkonfirmasi terbanyak dengan 34.366 kasus di kawasan Asia Tenggara diikuti oleh Indonesia dan Filipina dengan angka 26.473 dan 18.086 kasus.

Jumlah angka kasus COVID-19 di kawasan menunjukkan bahwa setiap negara di kawasan memiliki permasalahan yang serupa. ASEAN, institusi regional di kawasan Asia Tenggara yang membawahi 10 negara anggota dan berdiri semenjak tahun 1967, telah mengeluarkan beberapa inisiatif regional untuk menangani permasalahan wabah COVID-19 yang menyebar di kawasan. Salah satu inisiatif yang berhasil disepakati oleh negara anggota adalah COVID-19 Response Funds. Namun, terlepas dari inisiatif yang dicanangkan oleh ASEAN, realitas hubungan internasional di tengah krisis akan berimplikasi kepada dua kemungkinan, yaitu mendorong kolaborasi dengan sesama negara terdampak atau justru melakukan restriksi untuk penyelamatan diri yang dikenal sebagai mekanisme swabantu (self-help).

Kemungkinan terakhir telah dapat disaksikan oleh dunia saat ini, beberapa negara melakukan restriksi terhadap barang-barang esensial yang dibutuhkan di tengah pandemi. Pada bulan April, WTO menyampaikan bahwa terdapat 80 negara yang membatasi ekspor peralatan medis (Republika, 2020). Tensi antarnegara akan meningkat dan membuat negara mengambil langkah yang restriktif. Kecenderungan tersebut terjadi pada Amerika Serikat. Kekhawatiran terhadap survivalitas negaranya telah mendorong upaya proteksi ekstrem seperti yang dilakukan Amerika Serikat dengan pernyataan akan mengundurkan diri dan menarik pembiayaan permanen kepada WHO (New York Times, 2020).

Fenomena yang terjadi di dunia dengan pembatasan ekspor perlengkapan medis dan penarikan diri Amerika Serikat dari mekanisme Kerjasama melalui institusi WHO mendorong penulis untuk melihat lebih dekat bagaimana COVID- 19 berdampak terhadap corak relasi yang ada antara negara anggota ASEAN dengan institusi tersebut. Dalam 
memahami hal tersebut, penulis memilih negara Singapura sebagai objek analisa dikarenakan negara-kota tersebut merupakan salah satu negara yang memiliki kasus terkonfirmasi paling besar di kawasan dan merupakan negara dengan fenomena lonjakan kasus terbesar.

Metode yang digunakan merupakan metode kualitatif dengan menguraikan fenomena yang terkait perilaku Singapura dan ASEAN dalam hal penanganan wabah COVID-19. Adapun teknik pengumpulan data dilakukan dengan Studi Pustaka, sehingga data-data yang digunakan berasal dari laporan resmi pemerintah Singapura dan website resmi ASEAN, jurnal dan buku terkait relasi Singapura dan ASEAN serta artikel surat kabar daring yang berkorelasi dengan konteks isu yang dibahas oleh artikel ini.

Lebih lanjut, tulisan ini akan menampilkan relasi Singapura dan ASEAN di tengah COVID-19 yang menunjukkan corak Kerjasama dengan kolaborasi harmonis di level regional maupun bilateral. Penjelasan lebih lanjut terkait hal ini akan dibagi dalam tiga bagian yaitu pendahuluan, pembahasan serta kesimpulan. Bagian pembahasan sendiri akan terdiri dari lima aspek yang mewakili hubungan Singapura dan ASEAN secara umum, kondisi Singapura di tengah wabah COVID-19, refleksi dari respon Singapura dan ASEAN dalam penanganan wabah, dan analisa terkait corak relasi antara Singapura dan ASEAN serta peluang dan tantangan yang dihadapi oleh kedua belah pihak.

\section{Pembahasan}

\section{Titik Awal Hubungan Singapura dan ASEAN}

Singapura, seperti negara-negara lainnya di Asia Tenggara, memiliki nasib yang serupa yaitu tantangan untuk membangun bangsa (nationbuilding) di tengah perdebatan sengit di level sistem internasional yang terjadi akibat fragmentasi dua kubu kekuatan dari ideologi yang berbeda. Perang dingin antara Amerika Serikat dan Uni Soviet telah menyebabkan 
tensi yang muncul di kawasan Asia. Pertentangan keduanya telah mendorong munculnya gesekan dan proxy war, seperti yang terjadi di Semenanjung Korea pada tahun 1950-1953. Singapura pun harus menerima realita pahit dengan kondisi wilayah yang dikeluarkan dari negara Federasi Malaysia pada 9 Agustus 1945, selang dua tahun dari semenjak negara-kota tersebut bergabung di tahun 1963. Kondisi tersebut menandai tiga permasalahan yang dihadapi oleh Singapura yaitu, permasalahan pada level domestik terkait nation building, level kawasan yang tercermin melalui relasi dengan negara-negara tetangga dikawasan khususnya Malaysia, serta level sistem internasional dengan fenomena Perang Dingin yang mengancam kawasan.

Setiap negara di kawasan Asia Tenggara terlepas dari nasib yang serupa memiliki karakter domestik yang berbeda-beda. Kawasan Asia Tenggara terdiri dari keberagaman, baik dalam konteks pengalaman historis, budaya, agama dan pandangan strategis sehingga sulit untuk menciptakan Kerjasama yang solid di kawasan (Severino, 2006). Namun, perubahan outlook kebijakan dari Indonesia, sebagai salah satu negara dengan bagian wilayah terbesar di kawasan Asia Tenggara, menjadi salah satu katalis untuk meredakan perbedaan dan mendukung kolaborasi melalui pembentukan institusi ASEAN. Perubahan outlook kebijakan Indonesia dibawah rezim Soeharto mengakhiri Politik Konfrontasi Indonesia terhadap Malaysia dan Singapura dan menandai babak baru serta harapan untuk Kerjasama di kawasan (Narine, 2007). Alternasi sikap Indonesia melalui rezim Soeharto mengubah citra Indonesia yang awalnya dikenal sebagai negara yang sering membuat keributan pada periode 1960-an di kawasan menjadi promotor dalam terciptanya perdamaian di kawasan Asia Tenggara (Mochammad Yani dan Montratama, 2018).

Singapura menyadari kondisi dan resiko yang sedang dihadapi oleh negaranya di tengah upaya untuk melakukan national-building. Luas 
wilayah yang kecil dengan perbatasan darat dan laut yang diapit oleh negara tetangga dengan kapabilitas sumber daya yang relatif lebih besar seperti Malaysia dan Indonesia. Posisi tawar yang rendah sebagai negara baru dengan sumber daya yang terbatas mendorong ideology of survival menjadi arahan dari kebijakan luar negeri Singapura (Hiok, 1982). Berangkat dari kalkulasi untuk mempertahankan nasib bangsa yang sedang dibentuk, Singapura mengambil bagian sebagai salah satu dari 5 negara pemrakarsa ASEAN bersama Indonesia, Malaysia, Thailand dan Filipina di tahun 1967.

Keikutsertaan Singapura dalam ASEAN tidak terlepas sebagai upaya membangun identitas yang terafiliasi dengan identitas kawasan Asia Tenggara. Dari awal 1960-an, strategi People Action's Party (PAP) adalah untuk mencegah munculnya barisan kiri sosialis Pro-Mao, yang mencoba untuk membuat Singapura sebagai "Yenan" di Asia Tenggara (Kim, 1997). Terlebih sekitar $75 \%$ populasi mayoritas diisi oleh ras keturunan Cina. Singapura terus mengupayakan agar negara-kota diidentifikasi sebagai negara dengan masyarakat multi ras, multietnik dan multi religi dan memilih penggunaan bahasa inggris sebagai bahasa persatuan agar tidak mendapat klaim sebagai The Third China. Dengan permasalahan multidimensi yang dihadapi oleh Singapura, negara-kota ini berperan secara low profile pada fase awal bergabung dengan ASEAN.

Seperti yang telah disampaikan sebelumnya terkait ideology of survival sebagai logika serta mesin utama dalam menghasilkan kebijakan luar negeri Singapura, hal tersebut berimplikasi kepada dua hal yaitu penerapan pragmatisme ekonomi dan politik Singapura di ASEAN. Pragmatisme politik yang digunakan oleh negara-kota adalah dengan menggunakan ASEAN sebagai koneksi untuk meningkatkan dan memobilisasi kapabilitas pembentukan opini pada permasalahan internasional, sedangkan pragmatisme ekonomi diwujudkan melalui pandangan yang sedikit berbeda dengan negara anggota ASEAN lainnya, 
yaitu melalui penekanan terhadap global vision yang berorientasi outward looking (Rau, 1981).

Perbedaan visi ekonomi antarnegara anggota lainnya menjadi latar belakang mengapa terjadi hubungan yang fluktuatif antara ASEAN dan Singapura meskipun tidak berimplikasi pada pembubaran institusi. Dalam tulisan Constraint on Singapore Foreign Policy dijelaskan beberapa hal yang mendorong tensi di ASEAN (Hiok, 1982). Pertama Singapura dikritik karena tidak mengandalkan regional vision dan justru berpegang pada global vision. Kedua, Singapura dikritik sebagai negara kaya yang tidak mampu membantu negara tetangga dan ketiga Kerjasama ekonomi di ASEAN terbilang lambat untuk skala Singapura, belum lagi Singapura merasa kecewa terhadap banyaknya inisiatif ekonomi yang direncanakan tetapi tidak diimplementasikan seperti ASEAN Industrial Project di tahun 1977. Namun, tensi semacam ini dapat diatasi atas sinergi yang diciptakan oleh negara anggota dengan mengakomodasi kepentingan nasional dan kawasan secara bersamaan dapat berkontribusi terhadap pembangunan institusi yang lebih solid dan bertahan (Natalegawa, 2018).

\section{Transformasi kasus COVID-19 di Singapura: Awalnya dianggap Ideal, Selanjutnya dikritisi Tak Adil}

Singapura menjadi salah satu dari negara-negara yang mengkonfirmasi kasus COVID-19 di awal tahun. Kasus pertama merupakan "imported case" dari pria berusia 66 tahun yang baru tiba di Singapura tanggal 20 Januari 2020 dari Wuhan, China. Merespon kasus pertama, Singapura menerapkan langkah-langkah yang telah terkonsep dengan penerapan contact tracing (MOFA Singapore, 2020). Pelancong yang bepergian dengan pasien terkonfirmasi kasus diharuskan menjalani karantina selama 14 hari dan pemerintah melakukan pengawasan ketat terhadap orang-orang yang berinteraksi secara langsung dengan pasien. Singapura telah menyiapkan layanan Kesehatan yang terpadu dengan 
alokasi sumber daya medis seperti mobil Ambulans yang diarahkan khusus untuk penanganan wabah COVID-19.

Pada fase awal penyebaran COVID-19, Singapura tergolong sebagai negara yang menekankan upaya pencegahan yang ketat. Sosialisasi dilakukan kepada masyarakat melalui berbagai media, termasuk websitewebsite resmi dari Lembaga pemerintahan. Upaya pencegahan penyebaran wabah dilakukan dengan melakukan "travel restriction" bagi pengunjung dari Cina maupun pengunjung yang memiliki catatan kunjungan ke Cina (Reuters, 2020). Selain itu, pemerintah juga menggunakan teknologi untuk penanganan dan pencegahan penyebaran wabah dengan aplikasi "Trace Together" yang dikembangkan oleh Badan Teknologi Pemerintah dan Kementerian Kesehatan (Kompas, 2020).

Kebijakan di sektor ekonomi juga dikeluarkan oleh Singapura dalam rangka menangani permasalahan demand and supply shock yang terjadi secara bersamaan akibat dari COVID-19. Sejalan dengan permasalahan demand dan supply, Pemerintah memfasilitasi tiga jenis bantuan ${ }^{4}$ untuk mendorong agregat melalui 1) Skema dukungan pekerjaan (1,3 miliar dollar Singapura) dimana pemerintah membayar 8\% dari upah pekerja lokal selama tiga bulan, hingga batas bulanan 3.600 dolar Singapura. 2) Skema kredit upah (1,1 miliar dolar Singapura) dimana pemerintah mengeluarkan pendanaan bersama dengan kenaikan upah sekitar 30\% untuk karyawan Singapura, hingga upah bulanan kotor 5.000 dolar Singapura (parameter yang tepat meruncing seiring waktu) dan 3) Paket perawatan dan dukungan (1,6 miliar dollar Singapura) dimana pemerintah memberikan satu kali pembayaran tunai antara 100 dan 300 dollar Singapura untuk setiap warga Singapura berusia 21 atau lebih tinggi, sehingga membantu biaya pengeluaran rumah tangga (Quah, 2020).

\footnotetext{
${ }^{4}$ Skema penggelontoran dan aspek teknis pengajuan dijelaskan secara rinci melalui www.singaporebudget.gov.sg.
} 
Gambar 1. Jumlah Kasus Keseluruhan

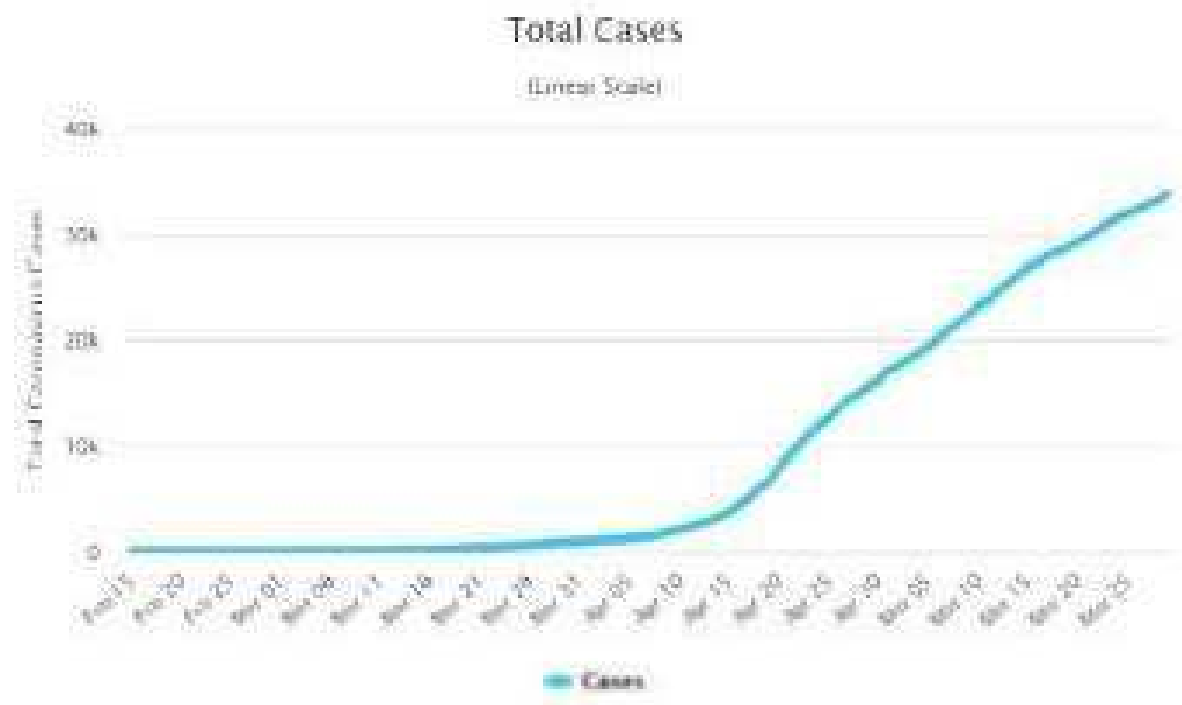

Gambar 2. Jumlah Kasus Harian

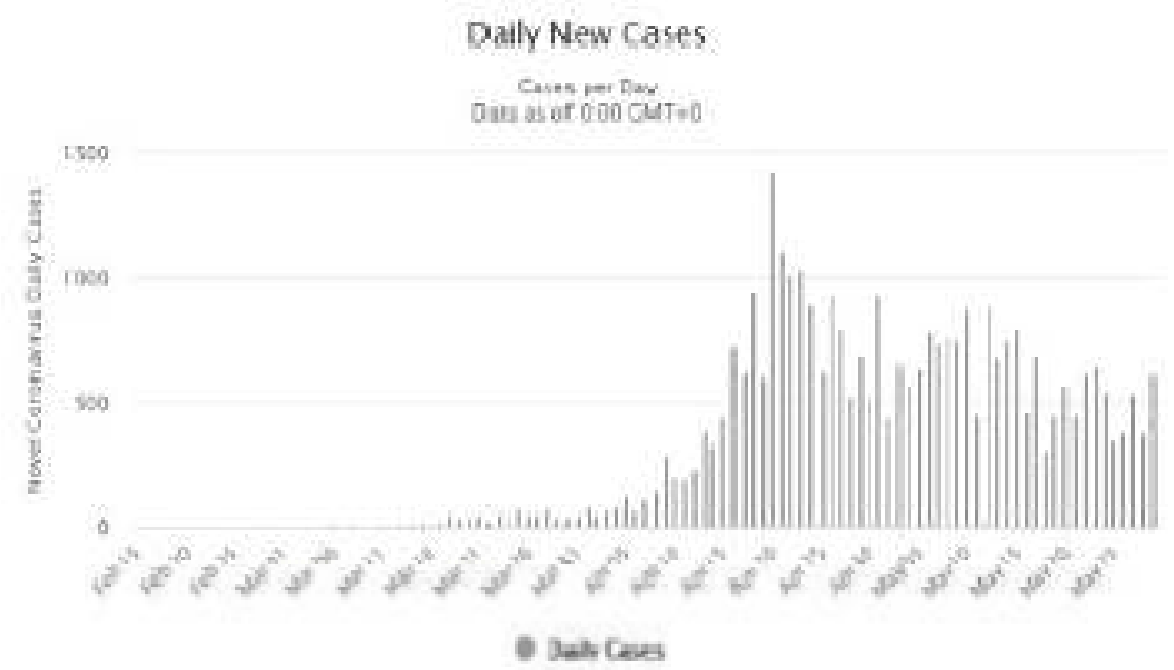

Sumber: Worldometers 5

Awalnya Singapura dikategorikan sebagai model ideal dari penanganan wabah COVID-19 karena pada periode pertama penyebaran, negara ini dapat menekan angka penyebaran tanpa harus menerapkan kebijakan sosial yang restriktif seperti lockdown total. Segala aktivitas

${ }^{5}$ Data yang ditampilkan mewakili angka kasus terkonfirmasi pada tanggal 31 Mei 2020 di website Worldometers.info 
sosial dapat berjalan dengan mekanisme social distancing, pencapaian tersebut tidak terlepas dari kemampuan negara dalam mengakomodasi penanganan COVID-19 yang tersentralisasi dan kesiapan sektor medis. Sayangnya, hal tersebut tidak berlangsung lama karena dimulai dari awal dan pertengahan bulan April terjadi peningkatan jumlah kasus yang signifikan (perhatikan tabel total kasus diatas). Jumlah kasus harian terus naik dengan angka tertinggi tercatat di pertengahan bulan April (perhatikan tabel kasus harian diatas). Dilansir artikel per tanggal 21 April, dalam tiga hari Singapura mencatat 3.000 jumlah kasus baru sehingga angka kasus terkonfirmasi di negara-kota tersebut meningkat tajam (The Guardian, 2020).

Peningkatan jumlah yang besar datang dari klaster baru, yaitu para pekerja migran yang tinggal di asrama padat di pinggiran kota. Pemerintah dianggap abai terhadap para pekerja migran karena tidak tanggap dalam menerapkan tracing dan testing dari kasus pekerja migran pertama yang terkonfirmasi. Kasus pekerja migran pertama kali diberitakan pada bulan Februari dimana pekerja laki-laki berusia 39 tahun dilaporkan positif COVID-19 (The Straits Time, 2020). Kondisi tersebut menimbulkan kritik terhadap Singapura oleh berbagai media dunia, seperti New York Times, The Guardian, The Diplomat, The Conversation and Foreign Policy. Pemerintah dianggap tidak melakukan kalkulasi kepada gejala asimtomatik, belum lagi Singapura dikritisi terkait penanganan yang tidak adil dengan melakukan lockdown dan isolasi total bagi para pekerja migran di infrastruktur yang kurang layak.

Pemerintah Singapura berdalih bahwa semua upaya yang dilakukan dalam menangani gelombang ke-2 COVID-19 didasari oleh perhitungan dan pertimbangan saintifik. Melalui website resmi Ministry of Foreign Affairs, Duta besar Singapura untuk Amerika Serikat, Ashok Kumar 
Mirpuri, mengirimkan surat terbuka untuk Editor dari Foreign Policy 6 terkait salah satu artikel yang dianggap memberikan pandangan keliru terkait penanganan kasus pada klaster pekerja migran di Singapura. Pemerintah Singapura menyampaikan bahwa tidak ada perbedaan antara penanganan kasus COVID-19 yang terjadi antara pekerja migran dan kasus yang terjadi diluar asrama. Semua penanganan kesehatan terkait COVID-19 diberikan gratis secara umum tanpa pengecualian.

Pemerintah melakukan strategi tiga cabang dalam penanganan wabah pada kluster ini, yaitu dengan menerapkan strategi social distancing untuk menekan penyebaran wabah, penempatan pos medis di setiap asrama sehingga pekerja migran yang mengalami permasalahan kesehatan dapat segera ditangani, dan terakhir, dengan menerapkan rezim pengujian yang agresif (MOFA Singapore, 2020). Kritik serta opini dunia terkait respon Pemerintah Singapura dalam penanganan kasus di klaster pekerja migran menjadi salah satu hal yang diperhatikan oleh Pemerintah. Opini dunia yang beririsan dengan aspek ketimpangan pada kasus pekerja migran di Singapura dapat berdampak pada posisi kredibilitas negara ketika akan mengeluarkan wacana normatif di forum pertemuan global. Oleh karena itu, Pemerintah melalui MOFA memberikan informasi terbuka sebagai counter-opinion serta gambaran terkait peran pemerintah dalam memastikan kehidupan dan penghidupan pekerja migran di tengah wabah COVID-19.

\section{Refleksi Hubungan Singapura dan ASEAN di tengah COVID-19}

Sebagai negara anggota dari ASEAN, Singapura ikut serta dalam segala bentuk pertemuan antar negara anggota yang dilakukan oleh

6 Duta Besar Singapura untuk Amerika menulis kepada Editor Foreign Policy terkait artikel berjudul "Singapore Is Trying to Forget Migrant Workers Are People" yang ditulis oleh Kirsten Han. Artikel ini mengkritisi Pemerintah Singapura yang dianggap memberikan tanggapan dan penanganan yang berbeda dalam penanganan kluster pekerja migran. Artikel tersebut berargumen bahwa pendekatan yang dilakukan oleh Pemerintah Singapura cenderung utilitarian dan tidak manusiawi. Artikel selengkapnya dapat diakses pada https://foreignpolicy.com/2020/05/06/singapore-coronavirus-pandemic-migrant-workers/. 
institusi sebagai respon terhadap COVID-19. ASEAN sendiri telah menginisiasi berbagai pertemuan sebagai media dalam proses pengambilan kebijakan di tingkat kawasan, pertemuan tingkat Kepala Negara dan Menteri dilakukan. Beberapa inisiatif muncul baik dari aspek keamanan, ekonomi dan kesehatan masyarakat melalui skema joint statement oleh Menteri pada sektor terkait. ${ }^{7}$ Kerjasama tidak terbatas dilakukan oleh negara anggota, ASEAN juga mengadakan pertemuan dengan negara Mitra Wicara seperti pada framework ASEAN Plus Three untuk menghasilkan upaya mitigasi dan penanganan wabah.

Salah satu output dari pertemuan yang disepakati oleh ke sepuluh negara adalah dengan dibentuknya Asean COVID-19 Respond Fund. Inisiatif ini diusulkan oleh Thailand dengan tujuan mengatasi kelangkaan pasokan medis yang disebabkan oleh wabah (The Jakarta Post, 2020). Berdirinya Asean COVID-19 Respond Fund dibawah keketuaan Vietnam sejalan dengan mandat yang termaktub pada Piagam Asean (2007) pada pasal 32 poin C “Negara Anggota yang memegang keketuaan ASEAN wajib: memastikan suatu tanggapan yang efektif dan tepat waktu terhadap isuisu mendesak atau situasi-situasi krisis yang mempengaruhi ASEAN, termasuk menyediakan jasa-jasa baik dan pengaturan-pengaturan lainnya guna menyelesaikan masalah-masalah dimaksud dengan segera (Piagam Asean, 2007)". Dana yang dikumpulkan untuk Asean COVID-19 Respond Fund berasal dari realokasi dana yang ada, dukungan teknis serta bantuan dana dari negara mitra khususnya yang terlibat dalam skema Asean Plus One dan Asean Plus Three (Widian dan Omega W, 2020). Inisiatif yang disepakati pada tanggal 14 April 2020 melalui Special Summit on Coronavirus Disease 2019 melalui video conference menunjukkan komitmen negara anggota untuk tidak melakukan

\footnotetext{
${ }^{7}$ Terdapat beberapa Joint Statement yang telah dikeluarkan sebagai bentuk komitmen ASEAN terhadap penanganan wabah di level regional seperti Joint statement of ASEAN Defence Ministers on Defence Cooperation against Disease Outbreak dan Joint Statement Special Video Conference of The ASEAN Health Ministers in Enhancing Cooperation on Coronavirus Disease 2019 (Covid-19) Response . Informasi lebih lanjut dapat diakses melalui https://asean.org/category/asean-statement-communiques/
} 
pembatasan yang tidak perlu pada arus barang, terutama barang strategis untuk memerangi COVID-19 seperti obat-obatan, makanan, dan persediaan penting. Melanjutkan Langkah kebijakan level regional tersebut, mendorong penggunaan Lembaga yang telah dibangun oleh ASEAN selama satu dekade, yakni ASEAN Coordinating Center for Humanitarian Assistance on Disaster Management (AHA Center) sebagai sarana memantau perkembangan pandemi di wilayah tersebut dan secara efektif menyalurkan semua sumbangan dan sumber daya selain membantu negara-negara anggota dengan manajemen krisis (The Jakarta Post, 2020).

Tidak terbatas pada pembentukan Asean COVID-19 Respond Fund, inisiatif pada level regional terus dilakukan oleh ASEAN Ministers on Agriculture and Forestry (AMAF). AMAF mengeluarkan joint statement pada 15 April 2020 yang menegaskan kembali komitmen untuk memastikan, keamanan pangan, dan nutrisi di kawasan selama wabah. AMAF berkomitmen untuk meminimalkan gangguan dalam rantai pasokan makanan regional dengan bekerja sama secara erat untuk memastikan bahwa pasar tetap terbuka dan transportasi produk pertanian dan makanan terfasilitasi dengan menekankan pentingnya mengurangi volatilitas harga yang berlebihan, terutama lonjakan harga, memastikan makanan dan cadangan darurat yang memadai dan memberikan informasi pasar yang tepat waktu dan akurat (ASEAN Secretariat, 2020). Singapura sendiri berusaha menginisiasi wacana terkait protokol baru yang memungkinkan pergerakan lintas batas orang di kawasan ASEAN, begitu pandemi COVID-19 mencapai tingkat yang dapat dikelola (The Jakarta Post, 2020).

Lebih lanjut, Upaya Singapura dalam menunjukkan komitmen pada penanganan COVID-19 di kawasan tidak hanya dilakukan melalui keikutsertaan negara terhadap pertemuan, komitmen dan persetujuan terhadap output kebijakan di level regional ataupun usulan terhadap 
pembentukan prosedur umum agar perjalanan antarnegara dapat kembali dibuka. Singapura menunjukkan solidaritas terhadap negara-negara anggota ASEAN di level bilateral. Berdasarkan press release yang diakses melalui website MOFA, Singapura aktif memberikan bantuan kepada negara-negara anggota ASEAN lainnya seperti Indonesia, Filipina, Myanmar, dan Brunei Darussalam. Bantuan yang diberikan oleh Singapura berupa alat tes diagnostik, mesin Polymerase Chain Reaction (PCR), Viral Transport Medium, Thermal Scanner, dan Personal Protective Equipment. ${ }^{8}$

Komitmen Singapura dalam berkolaborasi dengan negara anggota ASEAN tidak terbatas pada pemberian bantuan. Singapura bersama Malaysia menunjukkan komitmen yang positif dengan membentuk Special Working Committee on COVID-19. Working Committee dipimpin oleh Senior dan Menteri Koordinator Keamanan Nasional Teo Chee Hean, dan Menteri Senior Malaysia dan Menteri Pertahanan Dato Sri Ismail Sabri Yaakob dan Menteri Besar Johor Datuk Hasni. Kerjasama antara dua negara tersebut bertujuan untuk mengoordinasikan rencana mitigasi bersama untuk memastikan pergerakan orang, barang, dan layanan yang aman dan berkelanjutan antara Malaysia dan Singapura (MOFA Singapore, 2020).

\section{Singapura dan ASEAN : Gulirkan Iklim Kolaborasi di Kawasan}

Di tengah tingginya resiko negara-negara untuk melakukan proteksi, ASEAN telah menunjukkan komitmen yang serius dalam mengeluarkan respon kolektif dari negara-negara anggotanya. Kondisi krisis global yang disebabkan oleh wabah tidak membuat negara anggota memutuskan untuk menutup diri dan mengabaikan pertemuan-pertemuan pada level regional. Berbagai inisiatif dilakukan sebagai wujud cooperative culture

\footnotetext{
8 Jumlah bantuan yang diberikan kepada setiap negara berbeda-beda. Indonesia menjadi salah satu negara dengan jumlah dan variasi bantuan terbanyak. Singapura memberikan 30.000 alat tes diagnostik, 5 mesin PCR, 1.050 personal protective equipment, 100 viral transport medium, dan 4 thermal scanner. Bantuan disebarkan pada tiga wilayah di Indonesia, yaitu Jakarta, Riau dan Singapura.
} 
dari ASEAN yang tetap bergulir di tengah masa-masa krisis. Seperti yang dijelaskan pada bagian sebelumnya, ASEAN telah melaksanakan berbagai inisiatif untuk penanganan wabah di level regional. Salah satu pencapaiannya adalah dengan pembentukan ASEAN COVID-19 Response Funds yang akan dikelola oleh AHA Center.

Perilaku ASEAN di tengah wabah COVID-19 menunjukkan bahwa di tengah kondisi krisis ASEAN tetap berkomitmen untuk melakukan Kerjasama. ASEAN menjadi satu-satunya institusi kawasan pertama yang mempertahankan iklim kolaborasi di tengah tendensi negara-negara yang lebih mengutamakan mekanisme swabantu (self-help). COVID-19 sebagai wabah memberikan kerugian yang besar. Namun, terlepas dari itu juga menjadi pendorong untuk menggulirkan upaya Sentralitas ASEAN dalam menangani permasalahan-permasalahan yang dihadapi di kawasan.

Wabah ini juga kembali menunjukkan representasi ASEAN sebagai salah satu penopang arsitektur regional karena mampu mempertemukan negara yang saling bersaing untuk berbicara dan mengeluarkan pernyataan yang konstruktif untuk kawasan terkait COVID-19 seperti yang dilakukan oleh ASEAN dengan Cina, Jepang dan Korea dalam Joint Statement of the Special ASEAN Plus Three Summit on Coronavirus Disease 2019. Iklim Kerjasama pun ditunjukkan oleh negara Singapura dengan menunjukkan solidaritas terhadap negara-negara anggota ASEAN. Singapura secara aktif memberikan bantuan secara bilateral dengan negara-negara anggota seperti Indonesia, Filipina, Myanmar dan Brunei. Bantuan yang diberikan beragam dan esensial untuk upaya penanganan kasus COVID-19.

Semangat Kerjasama yang ditunjukkan oleh Singapura dengan perilaku solidaritas dan sikap kolektif negara anggota yang mengutamakan Sentralitas ASEAN dapat dibedah melalui Rational Choice Theory. Premis utama dari teori ini menunjukkan bahwa decision-makers cenderung melakukan perhitungan cermat dan rasional untuk 
memutuskan kebijakan yang berdaya guna (Hadiwinata, 2017). Kebijakan Luar Negeri Singapura berakar kepada ideology of survival sehingga berimplikasi kepada kebijakan yang cenderung pragmatis. Faktor determinan yang dimiliki Singapura khususnya terkait kapasitas sumber daya alam (natural endowment) yang terbatas mendorong Singapura untuk lebih terbuka dalam melakukan Kerjasama dengan negara-negara di kawasan.

Bantuan yang diberikan kepada negara-negara anggota ASEAN berkontribusi pada pembentukan iklim cooperative culture yang baik di institusi. Jaringan yang dibentuk melalui ASEAN memfasilitasi trustbuilding Singapura dengan negara anggota lainnya. Hal ini relevan dengan Kerjasama yang dibangun oleh Singapura dan Malaysia melalui SingaporeMalaysia Special Working Committee on COVID-19 yang mengkoordinasikan pergerakan orang, barang dan operasional harian antara dua negara. Melalui Kerjasama ini Singapura dapat memastikan bahwa akses kebutuhan esensial seperti pangan yang diproduksi oleh Malaysia tetap dapat diakses oleh Singapura meskipun terjadi krisis akibat wabah COVID-19.

Operasionalisasi Rational Choice Theory juga dapat menjelaskan mengapa di tengah krisis yang biasanya mendorong negara untuk melakukan langkah restriktif, ASEAN cenderung terbuka untuk melakukan Kerjasama. Penulis berargumen bahwa negara-negara anggota dari ASEAN menyadari bahwa dengan mencanangkan wacana secara kolektif dapat meningkatkan distribusi kapabilitas dari negara anggota secara keseluruhan sehingga dapat mendorong isu-isu normatif yang vital seperti keterbukaan akses vaksin untuk wabah. Peningkatan distribusi kapabilitas melalui aliansi yang difasilitasi oleh institusi memiliki implikasi terhadap peningkatan posisi tawar (bargaining position) dari setiap negara anggota di level sistem internasional. Oleh karena itu, negara-negara anggota memilih untuk tetap mempertahankan cooperative 
culture dengan mengedepankan sentralitas ASEAN di tengah wabah COVID-19 karena hal tersebut memfasilitasi tercapainya kepentingan nasional dan kawasan secara bersamaan.

\section{Peluang dan Tantangan Hubungan Singapura dan ASEAN}

Masa-masa krisis akan berimplikasi pada peluang dan tantangan tidak terkecuali bagi permasalahan wabah COVID-19 yang dihadapi oleh Singapura dan ASEAN. Penulis menilai bahwa kondisi krisis ini dapat menjadi peluang untuk menunjukkan eksistensi sebagai institusi regional yang akan berimplikasi kepada meningkatnya bargaining position dari negara anggota. Lebih jauh lagi, upaya penanganan permasalahan yang dihadapi kawasan dengan mengedepankan sentralitas ASEAN dapat mendorong legitimasi institusi sebagai penopang arsitektur regional dan yang krusial adalah kemudahan akses terhadap vaksin. Djalal dalam artikel yang dirilis oleh The Jakarta Post menyampaikan bahwa dibutuhkan kerjasama untuk menghadapi krisis yang dihadapi saat ini. Namun, terdapat setidaknya tiga permasalahan yang disampaikan pertama absennya Kerjasama intens di level internasional, kedua, ketakutan terhadap konsekuensi sosial dan ekonomi telah mendorong negara menerapkan mekanisme self-help. Terakhir, persaingan strategis antara Amerika Serikat dan Cina berkontribusi terhadap iklim internasional yang penuh ketegangan dan diisi oleh logika zero-sum game (The Jakarta Post, 2020).

Argumen Djalal dalam artikelnya mewakili kesulitan dan tantangan yang juga dihadapi oleh ASEAN. Namun, hal tersebut juga menunjukkan kesempatan ASEAN untuk menjadi penggerak wacana Kerjasama di level internasional khususnya terkait pengadaan vaksin yang terbuka dan dapat diakses oleh setiap negara tanpa pengecualian. Agar dapat mengambil peran vital dengan skala yang lebih luas, ASEAN dan negaranegara anggota perlu berkomitmen untuk menangani permasalahan 
wabah COVID-19 secara terpusat. Konsolidasi antarnegara anggota melalui komitmen untuk terus bergerak secara kolaboratif menjadi penting. Aspek ini memerlukan keikutsertaan setiap negara, termasuk Singapura.

Singapura harus mampu menjaga relasi dengan negara anggota ASEAN dengan tetap menunjukkan perilaku "good will" yang telah dilakukan dengan aksi solidaritas terhadap negara anggota ASEAN. Selanjutnya, negara-kota perlu untuk berfokus pada komitmen jangka panjang dengan tidak melakukan defeksi terhadap inisiatif kawasan. Hal ini tidak mudah bagi Singapura karena logika dasar dari kebijakan luar negeri berakar pada ideology of survival, sehingga pendekatannya akan pragmatis. Terlebih Singapura memiliki hubungan yang baik dengan external powers seperti Amerika Serikat dan Uni Eropa. Melihat realitas yang ada, penulis berargumen bahwa peluang yang dimiliki oleh Singapura dan ASEAN dalam menangani wabah COVID-19 akan tergantung dari bagaimana keduanya mampu mengatasi tantangan yang dihadapi, baik secara internal maupun eksternal.

\section{Kesimpulan}

Wabah COVID-19 berimplikasi pada perubahan corak relasi yang ada dalam sistem internasional. Corak relasi yang ada menunjukkan pada dua kemungkinan, kolaborasi melalui Kerjasama atau menerapkan batasan-batasan restriktif melalui proteksi. Melalui tulisan ini, penulis melihat relasi Singapura dan ASEAN mengarah terhadap corak pertama, yaitu penekanan kolaborasi melalui Kerjasama di kawasan. Simpulan ini didasarkan pada berbagai inisiatif regional yang sesuai dengan mandat Piagam ASEAN dalam rangka mitigasi permasalahan akibat wabah COVID-19 serta aksi solidaritas yang dilakukan oleh Singapura dengan mengirimkan bantuan kepada negara-negara tetangga seperti Indonesia, Filipina, Brunei dan Myanmar. Latar belakang corak relasi didasari pada perhitungan rasional dari logika untung-rugi yang akan didapatkan oleh 
kedua pihak yang menyadari bahwa langkah kolektif dapat mengakomodasi kepentingan kawasan dan kepentingan nasional dari negara anggota. Meskipun begitu, terdapat tantangan internal dan eksternal yang tetap harus dihadapi untuk dapat terus mendorong Sentralitas ASEAN dalam menangani kasus wabah COVID-19.

\section{DAFTAR PUSTAKA}

Agustin, D. (2020) 'WTO: 80 Negara Batasi Ekspor Peralatan Medis', Republika Online, 24 April. Tersedia dalam: https://republika.co.id/berita/q99q05383/wto-80-negara-batasiekspor-peralatan-medis (Akses: 1 Juni 2020)

Ang, J. (2020). ' Coronavirus: Family of infected Bangladeshi worker here to receive $\$ 10,000$ donation', The Straits Times, 24 Februari 2020. Tersedia dalam: https://www.straitstimes.com/singapore/coronavirus-family-ofinfected-bangladeshi-worker-here-to-receive-10000-donation(Akses: 24 Mei 2020)

Aravindan, A. (2020) 'Singapore bans China travelers to keep out coronavirus'. Reuters, 31 Januari 2020. Tersedia dalam : https://www.reuters.com/article/us-china-healthsingapore/singapore-bans-china-travelers-to-keep-out-coronavirusidUSKBN1ZU1A0 (Akses: 24 mei 2020)

ASEAN Secretariat. (2020). ASEAN pledges to ensure food security during COVID-19 outbreak [Press release]. 15 April 2020. Tersedia dalam : https://asean.org/asean-pledges-ensure-food-security-covid-19outbreak/ (Akses: 29 Mei 2020)

Beaumont, Peter. (2020). ' Singapore extends lockdown as Covid cases surge past 9,000', The Guardian, 21 April 2020. Tersedia dalam : https://www.theguardian.com/world/2020/apr/21/singaporecoronavirus-outbreak-surges-with-3000-new-cases-in-three-days (Akses: 24 mei 2020)

Bramasta, D. (2020) 'Singapura Gunakan Aplikasi "Trace Together" untuk Lacak Sebaran Covid-19', Kompas, 22 Maret 2020. Tersedia dalam: https://www.kompas.com/tren/read/2020/03/22/090200265/singa pura-gunakan-aplikasi-trace-together-untuk-lacak-sebaran-covid19?page $=1$ (Akses: 26 mei 2020)

Djalal, D. (2020). 'World desperately needs cooperation, leadership to beat COVID-19', The Jakarta Post, 29 Maret 2020. Tersedia dalam: 
https://www.thejakartapost.com/academia/2020/03/29/worlddesperately-needs-cooperation-leadership-to-beat-covid-19.html (Akses: 31 mei 2020)

Hadiwinata, BS. (2017). Studi dan Teori Hubungan Internasional: Arus Utama, Alternatif, dan Reflektivis, Jakarta: Yayasan Pustaka Obor Indonesia.

Hiok, LB. (1982). 'Constraints on Singapore's Foreign Policy', Asian Survey, 22(2), hal 524-535.

Kim, SP. (1997). 'Singapore and ASEAN: 1967-1997', Asian Journal of Political Science, vol 5(1) , hal 68-86

Ministry of Foreign Affairs (MOFA) Singapore. (2020) Singapore's Assistance to Indonesia to Fight COVID-19 [Press release]. 3 April 2020. Tersedia dalam: https://www.mfa.gov.sg/Newsroom/PressStatements-Transcripts-and-Photos/2020/04/20200403---COVIDIndonesia (Akses: 29 Mei 2020)

Ministry of Foreign Affairs (MOFA) Singapore. (2020) Singapore-Malaysia Special Working Committee on COVID-19 [Press release]. 20 Maret 2020. Tersedia dalam: https://www.mfa.gov.sg/Newsroom/PressStatements-Transcripts-and-Photos/2020/03/200320_SingaporeMalaysia-Special-Working-Committee-on-COVID(Akses: 29 Mei 2020)

Ministry of Foreign Affairs (MOFA) Singapore. (2020) Letter to the Editor Foreign Policy [Press release]. 27 Mei 2020. Tersedia dalam: https://www.mfa.gov.sg/Newsroom/Announcements-andHighlights/2020/05/20200528-Letter-to-the-Editor---Foreign-Policy (Akses: 29 Mei 2020)

Ministry of Foreign Affairs (MOFA) Singapore. (2020) Confirmed Imported Case Of Novel Coronavirus Infection In Singapore; Multi-Ministry Taskforce Ramps Up Precautionary Measures [Press release]. 23 Januari 2020. Tersedia dalam: https://www.mfa.gov.sg/Newsroom/Announcements-andHighlights/2020/01/23012020 (Akses: 29 Mei 2020)

Mochamad Yani, Y., \& Montratama, I. (2019). ' INDONESIA AND ASEAN IN 2025'. Jurnal Dinamika Global, 3(02), hal 135-153.

Narine, S. (2007). 'ASEAN into the twenty-first century: Problems and prospects', The Pacific Review, 13(3), hal 357-380.

Natalegawa, M. (2018). Does ASEAN Matter? A View from Within. Singapura: ISEAS- Yusof Ishak Institute.

Pakpahan, B. (2020). 'ASEAN: Mobilize AHA Center, all partners for COVID-19', The Jakarta Post, 20 April 2020. Tersedia dalam: 
https://www.thejakartapost.com/academia/2020/04/20/aseanmobilize-aha-center-all-partners-for-covid-19.html(Akses: 24 mei 2020)

Piagam ASEAN

Quah, D. (2020) Singapore's Policy Response, dalam Mitigating the COVID Economic Crisis: Act Fast and Do Whatever It Takes. London: VoxEU e-Book. Tersedia dalam: https://www.researchgate.net/publication/340339021_Singapore's_P olicy_Response_to_COVID-19> (Akses: 24 Mei 2020)

Rau, R. (1981). 'The Role of Singapore in ASEAN', Contemporary Southeast Asia, 3(2) , hal. 99-112.

Septiari, D. (2020). 'Leaders support establishment of ASEAN COVID-19 response fund', The Jakarta Post, 14 April 2020. Tersedia dalam: https://www.thejakartapost.com/seasia/2020/04/14/leaderssupport-establishment-of-asean-covid-19-response-fund.html (Akses: 23 mei 2020)

Severino, R. (2006). Southeast Asia in Search of an ASEAN Community. Singapura: ISEAS-Yusof Ishak Institute.

Shear, M, Jacobs, A. (2020)' W.H.O. Members Reject Trump's Demands but Agree to Study Its Virus Response', The New York Times, 19 Mei $2020 . \quad$ Tersedia https://www.nytimes.com/2020/05/19/us/politics/trump-whocoronavirus.html (Akses: 1 Juni 2020)

The Jakarta Post. (2020) 'Singapore to propose post-corona rules for ASEAN travel'. The Jakarta Post, 5 Mei 2020. Tersedia dalam: https://www.thejakartapost.com/seasia/2020/05/05/singapore-topropose-post-corona-protocol-for-asean.html (Akses: 27 mei 2020)

WHO, (2020), WHO Coronavirus Disease (COVID-19) Dashboard. Tersedia dalam : https://covid 19.who.int/ (Akses: 1 Juni 2020)

Widian, R., Omega W, V. (2020). " ASEAN Regional Potentials for Combating COVID-19', Jurnal Ilmiah Hubungan Internasional: Edisi Khusus, hal 31-38.

Worldometers, (2020), Singapore: Corona Virus Cases, Tersedia dalam: https://www.worldometers.info/coronavirus/country/singapore/( Akses: 31 Mei 2020) 